\title{
Disease Course in Hospitalized COVID-19 Patients with and without Rheumatic Disease and Its Relationship with Immunosuppressive Drug Use
}

\author{
Hastanede Yatan COVID-19 Hastalarında Romatolojik Hastalığı Olan ve Olmayanlarda \\ Hastalığın Seyri ve Immünsüpresif Ilaç Kullanımı ile Ilişskisi
}

\author{
(D) Selime ERMURAT ${ }^{1}$, (1) Koray AYAR ${ }^{1}$, (D) Suna AVCI ${ }^{2}$, (D Vildan GÜRSOY ${ }^{3}$ \\ 1 University of Health Sciences Turkey, Bursa Yüksek ihtisas Training and Research Hospital, Clinic of Rheumatology, Bursa, Turkey \\ 2University of Health Sciences Turkey, Bursa Yüksek ihtisas Training and Research Hospital, Clinic of Geriatrics, Bursa, Turkey \\ 3Uşak University Faculty of Medicine, Department of Hematology, Uşak, Turkey
}

\section{Abstract}

Introduction: This study aims to determine the course of Coronavirus disease-2019 (COVID-19) with rheumatic diseases (RDs) and to evaluate the effects of immunosuppressive (IS) drugs on the severity of COVID-19.

Materials and Methods: A total of 1905 patients comprising 988 women and 917 men were hospitalized for COVID-19 and were retrospectively analyzed. A total of 57 of them were rheumatic patients (RPs). Rheumatic patients and non-RPs were compared in terms of IS drugs, demographic characteristics, comorbidities, drugs used in the treatment of COVID-19, laboratory and thorax tomography results, and duration of hospitalization (DOH), intensive care unit (ICU), and mortality rates. Patients taking IS drugs were determined as IS patients. Immunosuppressive and non-IS patients were also compared. The effects of each IS drug on the presence of pneumonia, DOH, ICU, and mortality frequency, and poor prognostic factors were further evaluated.

Results: Pneumonia $(p=0.358), D O H(p=0.650), I C U(p=0.386)$, and mortality rates $(p=0.386)$ were non significant between RPs and non-RPs. Duration of hospitalization ( $p=0.881)$, ICU $(p=0.176)$, and mortality rates $(p=0.176)$ between patients with RDs receiving IS and not receiving IS drugs were also non significant. Intensive care unit $(p=0.003)$ and mortality $(p=0.035)$ rates were significantly higher in RPs receiving sulfasalazine (SSZ). Rheumatic patients receiving cyclosporine A (CsA) had significantly less pneumonia $(p=0.040)$. C-reactive protein level was significantly lower in $\mathrm{RPs}$ receiving $\operatorname{Cs} A(p=0.022)$ and hydroxychloroquine ( $p=0.033)$.

Conclusion: The presence of RD did not affect the course of COVID-19 disease. Sulfasalazine had a negative effect on the course of COVID-19 disease, whereas CsA had a positive effect. The effect of CsA and SSZ on COVID-19 pneumonia needs to be evaluated with further studies.

Keywords: Rheumatic diseases, COVID-19, immunosuppressive drugs

\section{Öz}

Giriş: Bu çalışma, romatizmal hastalığı olan hastalarda Koronavirüs hastalığı-2019'un (COVID-19) seyrini belirlemeyi ve immünosüpresif (IS) ilaçların COVID-19 şiddeti üzerindeki etkilerini değerlendirmeyi amaçlamaktadır.

Gereç ve Yöntem: Koronavirüs hastalığı-2019 nedeniyle hastaneye yatırılan 988'i kadın ve 917'si erkek, 57'si romatizmal hasta olmak üzere toplam 1,905 hastanın verileri geriye dönük olarak analiz edildi. İmmünosüpresif ilaçlar, demografik özellikler, komorbiditeler, COVID-19 tedavisinde kullanılan ilaçlar, laboratuvar ve toraks tomografi sonuçları, hastanede kalış süresi (HKS), yoğun bakım ünitesi (YBÜ) ve ölüm oranları romatizmal hastalar ile romatizmal olmayan hastalar arasında karşılaştıııldı. Ayrıca iS olan ve olmayan hastalar da karşılaştırıldı. Her bir iS ilacın pnömoni varlığı, HKS, YBÜ ve mortalite sıklığı ve kötü prognostik faktörler üzerindeki etkileri ayrıca değerlendirildi.

Bulgular: Pnömoni $(p=0,358)$, HKS $(p=0,650)$, YBÜ $(p=0,386)$ ve ölüm oranları $(p=0,386)$ romatolojik hasta ve romatolojik olmayan hastalarda benzer bulundu. Hastanede kalış süresi $(p=0,881)$, YBÜ $(p=0,176)$ ve mortalite oranları $(p=0,176)$ iS alan ve almayan romatoloji hastaları arasında 
farklı değildi. Sülfasalazin (SLZ) alan romatolojik hastalarda YBÜ $(p=0,003)$ ve mortalite $(p=0,035)$ oranları anlamlı olarak daha yüksekti. Siklosporin A (CsA) alan romatolojik hastalarda anlamlı olarak daha az pnömoni vardı $(p=0,040)$. Siklosporin $A(p=0,022)$ ve hidroksiklorokin alan romatolojik hastalarda C-reaktif protein düzeyi anlamlı olarak daha düşüktü $(p=0,033)$.

Sonuç: Romatolojik hastalık varlığının COVID-19 hastalığının seyrini etkilemediği bulundu. Sülfasalazin, COVID-19 hastalığının seyrini olumsuz etkileyebilirken, CsA olumlu etkiliyor olabilir. Siklosporin A ve SLZ'nin COVID-19 pnömonisi üzerindeki etkisinin ileri çalışmalarla değerlendirilmesi gerekmektedir.

Anahtar Kelimeler: Romatolojik hastalıklar, COVID-19, immünsüpresif ilaçlar

\section{Introduction}

Coronavirus disease-2019 (COVID-19), caused by severe acute respiratory syndrome coronavirus-2 (SARS-CoV-2) has progressed rapidly into a worldwide pandemic. The SARSCoV-2 infection has a heterogenous disease course. It may be asymptomatic or cause only mild symptoms in the majority of the cases. However, it can drive profound immunological complications such as macrophage activation syndrome, resulting in cytokine storm syndrome and acute respiratory distress syndrome (ARDS) in some patients ${ }^{[1]}$. The progression to ARDS in COVID-19 is associated with the manifestation of excessive release of inflammatory cytokines, especially interleukin (IL)-2, IL-6, IL-10, IL-12, and tumor necrosis factor- $\alpha^{[2]}$. It is believed that anti-inflammatory therapies may benefit the severely affected patients as hyperinflammation is the underlying factor of severe COVID-19. Some pathologies also cause rheumatic diseases (RDs) in the immune system, and anti-inflammatory drugs are used for the treatment of RDs ${ }^{[3]}$. Recently, it has been reported that a few antirheumatic drugs, including chloroquine, hydroxychloroquine (HCO), JAK inhibitors, IL-6 and IL-1 inhibitors, glucocorticoids (GC), intravenous immunoglobulin (IVIG), and colchicine are used for the treatment of patients with mild or severe COVID-19 $9^{[2,3]}$. However, data on the susceptibility, disease severity, and prognosis of COVID-19 in patients with RDs on immunosuppressants is still lacking. More observation data about the prevalence and severity of COVID-19 in patients with RDs and experience managing such cases are needed.

This study aims to compare the course of COVID-19 in hospitalized rheumatic patients (RPs) and non-RPs, and to evaluate the effect of IS drugs used in COVID-19 patients with RDs on the course and severity of the disease.

\section{Materials and Methods}

\section{Study Population and Design}

Ethics committee approval was obtained from the Bursa Yüksek Intisas Training and Research Hospital Ethics Committee, dated 24.06.2020 and numbered 2011-KAEK-25 2020/06-10. National permits were then obtained from the Bursa Provincial Public Health Directorate, which is included in the combat against the COVID-19 pandemic. Thus, all stages of the study complied with the Declaration of Helsinki.

\section{Data Collection}

Electronic files of 1,928 patients admitted to Bursa Yüksek Ihtisas Training and Research Hospital with a diagnosis of COVID-19 between 16.03 .2020 and 31.05 .2020 were retrospectively analyzed. These patients were diagnosed with COVID-19 in line with the interim guidance ${ }^{[4]}$. Positive polymerase chain reaction (PCR) tests were considered "definite" cases. Cases of negative PCR tests that were accompanied by symptoms such as fever, sore throat, shortness of breath, cough, loss of smell, low oxygen saturation, and "typical" radiographic results were accepted as a "possible" COVID-19 infection if there is no other reason to explain the symptoms ${ }^{[5]}$. Peripheral, bilateral (multilobar), and multifocal round ground-glass opacities were considered "typical" radiographic results. Round or non-peripheral multifocal, diffuse, perihilar, or unilateral ground-glass opacities were considered "uncertain" radiological results ${ }^{[4,6]}$.

Demographic characteristics, comorbidities, IS drugs, laboratory results, thorax computed tomography (CT) results, drugs used in the treatment of COVID-19, duration of hospitalization (DOH) intensive care unit (ICU), and mortality rates of the patients were recorded.

\section{Determination of Groups and Inclusion-exclusion Criteria}

The patients were divided into two groups as RPs and nonRPs. Patients who were previously evaluated and diagnosed by a rheumatologist and whose International Classification of Diseases-10 diagnosis code was entered into the hospital system were included in the RPs group. Patients except RPs were determined as a non-rheumatological group. Patients under the age of 18 , outpatients, patients with inaccessible data, cancer patients, and patients receiving IS drugs for any reason other than RDs were not included in the study.

\section{Rheumatic Patients with and without Immunosuppressive Use}

Rheumatic patients were divided into two groups as IS patients and non-IS patients. Glucocorticoids, methotrexate (MTX), leflunomide (LEF), sulfasalazine (SSZ), cyclosporine (CsA), azathioprine, tacrolimus (TAC), and/or biological agents were categorized as IS drugs. Patients taking these IS drugs were determined as IS patients. Hydroxychloroquine, colchicine, duloxetine, pregabalin, and/or non-steroidal anti-inflammatory 
drugs (NSAIDs) were categorized as non-IS drugs. Patients using non-IS drugs were determined as non-IS patients. The presence of pneumonia, DOH, ICU, and mortality rates, and poor prognostic factors were evaluated and compared between RPs and non-RPs as well as between IS and non-IS patients. High C-reactive protein (CRP), lymphocyte, ferritin, and D-dimer were determined as poor prognostic factors under the COVID-19 interim treatment guidelines ${ }^{[7]}$.

\section{Statistical Analysis}

The data analysis was performed using IBM Statistical Package for the Social Sciences 21.0 statistics package software. Whether the data were normally distributed was evaluated by Kolmogorov-Smirnov or Shapiro-Wilk tests. The Student's t-test was used for continuous variables with normal distribution, and the Mann-Whitney $\mathrm{U}$ test was used for continuous variables without normal distribution. Chi-square $\left(\chi^{2}\right)$ test or Fisher's exact test was used to compare qualitative variables between groups. The relationship of quantitative variables with each other was evaluated by Spearman's correlation analysis. P value $<0.05$ was considered statistically significant.

\section{Results}

A total of 1,905 patients who met the criteria among 1,928 patients hospitalized with a diagnosis of COVID-19 were included in the study. Fifty seven of whom were diagnosed with RD. The mean age of the patients included in the study was $51.18 \pm 21.24$ years, and $59.9 \%$ were female. The mean age of RPs was $57.72 \pm 16.53$ years, and $80.4 \%$ of RPs were female. The distribution of accompanying RDs in the RPs group is shown in Figure 1. The distribution of RDs was as follows: rheumatoid arthritis, 40.4\% ( $n=23)$; ankylosing spondylitis, 10.5\% $(n=6)$ : familial Mediterranean fever (FMF), 8.8\% $(n=5)$; Sjögren's syndrome, $8.8 \%(n=5)$; systemic lupus erythematosus (SLE), $8.8 \%(n=5)$; Behçet's disease, 5.3\% $(n=3)$; psoriatic arthritis (PSA), $5.3 \%(n=3)$; systemic sclerosis, $3.5 \%(n=2)$; polymyalgia rheumatica, 3.5\% $(n=2)$; fibromyalgia, 3.5\% $(n=2)$; and gout, $1.8 \%(n=1)$.

\section{Comparison of COVID-19 Patients with and without Rheumatic Disease}

Comparison of demographic characteristics, comorbidities, drugs, and outcomes between RPs and non-RPs hospitalized for SARS-CoV-2 infection is shown in Table 1. The gender distribution was found to be different between the groups $(p=<0.001)$ even though the median age was not different $(p=0.071)$. The percentage of females was higher in patients with RPs (84.2\% vs 50.9\%). The presence of comorbidities including diabetes mellitus, hypertension, chronic heart failure, and chronic renal failure was significantly high in patients with RDs ( $p=0.032, p<0.001, p<0.001, p=0.001$, respectively).

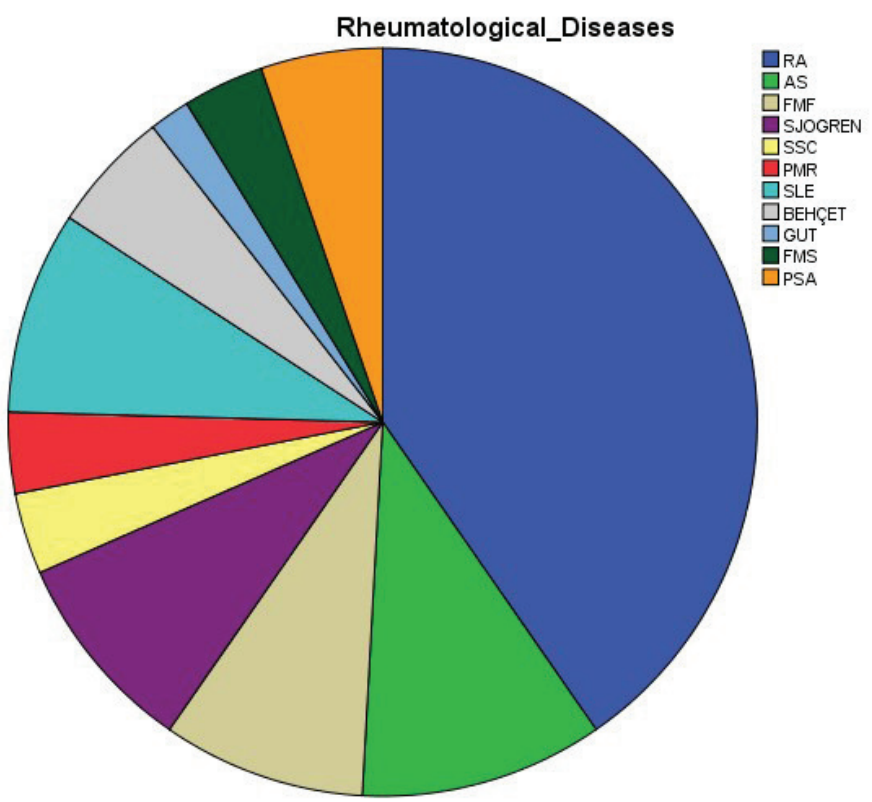

Figure 1. Distribution of rheumatological diseases

RA: Rheumatoid arthritis, AS: Ankylosing spondylitis, FMF: Familial Mediterranean fever, SSC: Systemic sclerosis, PMR: Polymyalgia rheumatica, SLE: Systemic lupus erythematosus, FMS: Fibromyalgia syndrome, PSA: Psoriatic arthritis

The frequency of pneumonia and outcome parameters were similar in both groups. The frequency of each drug used in the treatment of COVID-19 and the outcomes parameters were not different between the groups.

\section{Comparison of COVID-19 Patients with and without Immunosuppressive Drugs}

The comparison of demographic data, comorbidities, COVID-19 treatments, and outcome parameters in RPs with and without IS drugs are shown in Table 2. Among the RPs, $70.2 \%(n=40)$ of them were receiving at least one IS drug. There was no significant difference between the age, gender distribution, comorbidities, laboratory and radiological results, and the drugs used in the treatment of COVID-19 between IS and non-IS patients. In addition, there was no difference between the groups in terms of DOH ( $p=0.881)$, ICU ( $p=0.176)$, and mortality rates ( $p=0.176)$.

$P$ values showing the effect of antirheumatic drugs on poor prognostic factors are shown in Table 3. There was no significant effect of GC, NSAIDs, MTX, LEF, colchicine, and TAC on poor prognostic factors. Intensive care unit and mortality rates were higher in patients receiving SSZ than those who did not ( $p=0.003, p=0.035$, respectively). Intensive care unit and mortality rates were $40 \%$ in patients receiving SSZ whereas $3.8 \%$ in patients not receiving SSZ. It was found that patients receiving CsA had significantly less pneumonia $(p=0.040)$, and CRP was significantly lower in patients receiving $\operatorname{CsA}(p=0.022)$. The frequency of pneumonia on CT was $25 \%$ in patients 
Table 1. Comparison of demographic characteristics, comorbidities, drugs, and outcomes between patients with and without rheumatic disease hospitalized for COVID-19 infection

\begin{tabular}{|c|c|c|c|}
\hline & $\begin{array}{l}\text { Patients with } \\
\text { rheumatic } \\
\text { disease } \\
(n=57)\end{array}$ & $\begin{array}{l}\text { Patients } \\
\text { without } \\
\text { rheumatic } \\
\text { disease } \\
(n=1848)\end{array}$ & $\mathbf{p}$ \\
\hline $\begin{array}{l}\text { Age, years, median } \\
\text { (min-max) }\end{array}$ & $57(20-91)$ & 54 (18-99) & 0.071 \\
\hline Female, n (\%) & $48(84.2)$ & $940(50.9)$ & $<0.001$ \\
\hline \multicolumn{4}{|l|}{ Comorbidities, n (\%) } \\
\hline Diabetes mellitus & $13(22.80)$ & 240 (12.98) & 0.032 \\
\hline Hypertension & $29(50.87)$ & $418(22.62)$ & 0.000 \\
\hline Cardiovascular disease & $9(15.78)$ & $64(3.46)$ & $<0.001$ \\
\hline Chronic renal failure & $6(10.52)$ & $38(2.05)$ & 0.001 \\
\hline Pneumonia by CT, n (\%) & $34(59.64)$ & $880(47.61)$ & 0.358 \\
\hline \multicolumn{4}{|l|}{$\begin{array}{l}\text { COVID-19 medication, } \\
\mathrm{n}(\%)\end{array}$} \\
\hline Hydroxychloroquine & $57(100)$ & 1838 (99.45) & 0.833 \\
\hline Oseltamivir & $30(52.63)$ & $888(48.05)$ & 0.317 \\
\hline Azithromycin & $35(61.40)$ & $1186(64.17)$ & 0.367 \\
\hline $\begin{array}{l}\text { Low molecular weight } \\
\text { heparin }\end{array}$ & $40(70.17)$ & $1097(59.36)$ & 0.065 \\
\hline Favipiravir & $7(12.28)$ & $215(11.6)$ & 0.512 \\
\hline Tocilizumab & $0(0)$ & $8(0.43)$ & 0.782 \\
\hline \multicolumn{4}{|l|}{ Outcome } \\
\hline $\begin{array}{l}\text { TOH, day, median } \\
\text { (min-max) }\end{array}$ & $5(1-21)$ & $5(1-59)$ & 0.650 \\
\hline TOH, day, n (\%) & & & 0.880 \\
\hline$<10$ days & $48(84.2)$ & $1595(86.7)$ & \\
\hline 11-20 days & $8(14)$ & $207(11.2)$ & \\
\hline 21-30 days & $1(1,8)$ & $30(1.6)$ & \\
\hline$>30$ days & $0(0)$ & $8(0.4)$ & \\
\hline ICU, n (\%) & $4(7.01)$ & $101(5.4)$ & 0.386 \\
\hline Mortality rate, n (\%) & $4(7.01)$ & $106(5.73)$ & 0.568 \\
\hline
\end{tabular}

receiving CsA whereas $65.3 \%$ in patients not receiving CsA. Median CRP was 5.7 (3.14-15.3) $\mathrm{mg} / \mathrm{L}$ in patients receiving CsA and 21.4 (3.11-183) $\mathrm{mg} / \mathrm{L}$ in those who did not receive CsA. The median CRP was significantly high in patients receiving $\mathrm{HCO}$ ( $p=0.033)$; CRP was $45.1(3.11-163) \mathrm{mg} / \mathrm{L}$ in patients receiving $\mathrm{HCO}$ whereas it was 14 (3.11-183) in patients not receiving HCO.

\section{Mortality in Rheumatic Patients}

Mortality rate in patients with RDs was 7\% $(n=4)$. The mean age of the RPs who died was $65.25 \pm 18.5$ years. Three of four RPs were male. Three of the patients were diagnosed with $\mathrm{RA}$; they all received IS drugs, and all of them had multiple
Table 2. The comparison of demographic data, comorbidities, COVID-19 treatments, and outcome parameters in rheumatic disease patients receiving and not receiving immunosuppressive drugs

\begin{tabular}{|c|c|c|c|}
\hline & $\begin{array}{l}\text { Patients } \\
\text { receiving IS } \\
\text { drugs }(n=40)\end{array}$ & $\begin{array}{l}\text { Patients not } \\
\text { receiving IS } \\
\text { drugs }(n=17)\end{array}$ & $\begin{array}{l}p \\
\text { value }\end{array}$ \\
\hline 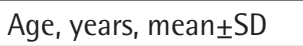 & $58.8 \pm 15.85$ & $55 \pm 18.23$ & 0.553 \\
\hline Female, n (\%) & $35(87.5)$ & $13(76.5)$ & 0.252 \\
\hline \multicolumn{4}{|l|}{ Comorbidities, n (\%) } \\
\hline Diabetes mellitus & $8(20)$ & $5(29.41)$ & 0.327 \\
\hline Hypertension & $23(57.5)$ & $6(35.29)$ & 0.106 \\
\hline COPD & $6(15)$ & $2(11.76)$ & 0.554 \\
\hline Cardiovascular disease & $8(20)$ & $1(5.88)$ & 0.176 \\
\hline Chronic renal failure & $4(10)$ & $2(11.76)$ & 0.527 \\
\hline \multicolumn{4}{|l|}{ Acute phase reactants } \\
\hline $\mathrm{ESR}, \mathrm{mm} / \mathrm{h}, \mathrm{mean}_{ \pm} \mathrm{SD}$ & $54.23 \pm 25.56$ & $48.14 \pm 26.00$ & 0.991 \\
\hline $\mathrm{CRP}, \mathrm{mg} / \mathrm{L}$, median & $18.3(3.11-183)$ & $16.8(3.11-177)$ & 0.782 \\
\hline \multicolumn{4}{|l|}{$\mathrm{CBC}$ mean $\pm \mathrm{SD}$} \\
\hline WBC, $10^{3}$ cells $/ \mu \mathrm{l}$ & $6.45 \pm 3.25$ & $6.29 \pm 2.17$ & 0.164 \\
\hline Lym, $10^{3}$ cells/ul & $1.67 \pm 0.57$ & $1.56 \pm 0.62$ & 0.190 \\
\hline $\mathrm{Hb}, \mathrm{g} / \mathrm{dl}$ & $11.55 \pm 1.89$ & $12.12 \pm 1.40$ & 0.201 \\
\hline PLT, $10^{3}$ cells $/ \mu \mathrm{l}$ & $234 \pm 90$ & $248 \pm 72$ & 0.302 \\
\hline \multicolumn{4}{|c|}{ Biochemical and hormonal parameters, median (min-max) } \\
\hline Ferritin, ng/ml & $110(16-370)$ & $70.88(19-496)$ & 0.327 \\
\hline Creatinine, mg/dl & $0.69(0.27-7.04)$ & $0.9(0.41-1.59)$ & 0.441 \\
\hline D-dimer, $\mu \mathrm{g} / \mathrm{ml}$ & $0.64(0.19-5.36)$ & $0.82(0.30-2.47)$ & 0.487 \\
\hline Troponin, pg/ml & $4.55(3-335)$ & $3.68(3-23.47)$ & 0.645 \\
\hline Fibrinogen, mg/dl & $397(181-900)$ & $466(138-900)$ & 0.840 \\
\hline Pneumonia by $\mathrm{CT}$, n (\%) & $25(62.5)$ & $9(52.94)$ & 0.351 \\
\hline \multicolumn{4}{|c|}{ COVID-19 medication, $\mathrm{n}(\%)$} \\
\hline Hydroxychloroquine & $40(100)$ & $17(100)$ & 1.000 \\
\hline Oseltamivir & $19(47.5)$ & $11(64.70)$ & 0.184 \\
\hline Azithromycin & $25(62.5)$ & $10(58.82)$ & 0.511 \\
\hline $\begin{array}{l}\text { Low molecular weight } \\
\text { heparin }\end{array}$ & $28(70)$ & 12 (70.59) & 0.613 \\
\hline Favipiravir & $4(10)$ & $3(17.64)$ & 0.344 \\
\hline \multicolumn{4}{|c|}{ Parameters of outcome } \\
\hline $\begin{array}{l}\text { DOH, day, median } \\
\text { (min-max) }\end{array}$ & $5(1-19)$ & $5(1-21)$ & 0.881 \\
\hline DOH, day, n (\%) & & & 0.293 \\
\hline$<10$ days & $34(85)$ & $14(82.35)$ & \\
\hline $11-20$ days & $6(15)$ & $2(11.76)$ & \\
\hline $21-30$ days & $0(0)$ & $1(5.8)$ & \\
\hline ICU, n (\%) & $4(10)$ & $0(0)$ & 0.176 \\
\hline Mortality rate, n (\%) & $4(10)$ & $0(0)$ & 0.176 \\
\hline \multicolumn{4}{|c|}{$\begin{array}{l}\text { COVID-19: Coronavirus disease-2019, IS: Immunosuppressive, COPD: Chronic } \\
\text { obstructive pulmonary disease, ESR: Erythrocyte sedimentation rate, CRP: C-reactive } \\
\text { protein, CBC: Complete blood count, WBC: White blood cell, Lym: Lymphocyte, Hb: } \\
\text { Hemoglobin, PLT: Platelet, DOH: Duration of hospitalization, ICU: Intensive care unit, } \\
\text { SD: Standard deviation, CT: Computed tomography, min-max: Minimum-maximum }\end{array}$} \\
\hline
\end{tabular}


Table 3. P values showing the effect of antirheumatic drugs on poor prognostic factors

\begin{tabular}{|c|c|c|c|c|c|c|c|c|}
\hline & Pneumonia & CRP & Lym & Ferritin & D-dimer & $\mathrm{DOH}$ & ICU & Mortality \\
\hline Glucocorticoids, $(n=22)$ & 0.407 & 0.070 & 0.718 & 0.406 & 0.817 & 0.868 & 0.121 & 0.155 \\
\hline Hydroxychloroquine, $(n=17)$ & 0.140 & $0.033^{1}$ & 0.179 & 0.883 & 0.886 & 0.525 & 0.827 & 0.827 \\
\hline Colchicine, $(n=10)$ & 0.287 & 0.915 & 0.867 & 0.316 & 0.201 & 0.274 & 0.684 & 0.548 \\
\hline Methotrexate, $(n=14)$ & 0.124 & 0.080 & 0.718 & 0.968 & 0.588 & 0.297 & 0.220 & 0.250 \\
\hline Leflunomide, $(n=6)$ & 0.208 & 0.853 & 0.435 & 0.851 & 0.726 & 0.286 & 0.477 & 0.477 \\
\hline Sulfasalazine, $(n=5)$ & 0.074 & 0.189 & 0.594 & 0.242 & 0.059 & 1.000 & $0.003^{2}$ & $0.035^{2}$ \\
\hline Cyclosporine, $(n=8)$ & $0.040^{3}$ & $0.022^{3}$ & 0.190 & 0.661 & 0.120 & 0.569 & 0.402 & 0.536 \\
\hline Tacrolimus, $(n=1)$ & 0.404 & 0.114 & 0.101 & 0.916 & 0.844 & 0.580 & 0.782 & 0.930 \\
\hline Azathioprine, $(n=1)$ & 0.220 & 0.780 & 0.301 & $-^{*}$ & $-^{*}$ & 0.103 & 0.782 & 0.782 \\
\hline TNF inhibitors, $(n=1)$ & 0.227 & 0.663 & 0.377 & 0.346 & 0.227 & 0.602 & 0.786 & 0.786 \\
\hline NSAID, $(n=5)$ & 0.074 & 0.342 & 0.413 & 0.260 & 0.493 & 0.179 & 0.315 & 0.315 \\
\hline
\end{tabular}

'Lower CRP was seen in patients receiving hydroxychloroquine.

${ }^{2}$ Intensive care units and mortality rates were more frequent in patients receiving sulfasalazine.

${ }^{3}$ Less pneumonia and lower CRP were seen in patients receiving cyclosporine.

*The $p$ value could not be calculated since the ferritin and fibrinogen levels of the only patient receiving azathioprine were not calculated.

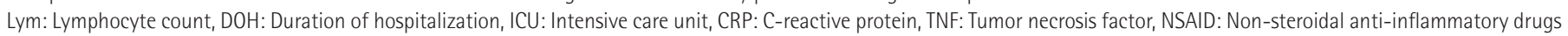

comorbidities. Another patient's diagnosis was FMF; she was receiving colchicine and had no accompanying comorbidity.

\section{Discussion}

It was noted in this study that hospitalized COVID-19 patients with RDs had more comorbidity compared to non-RPs. However, the outcomes such as DOH, ICU, and mortality rates were not different between RPs and non-RPs. In addition, antirheumatic drugs did not affect the course of COVID-19 nor the outcomes except CsA and SSZ; the disease progressed better in patients receiving CsA but worse in patients receiving SSZ in our study.

Patients with RDs who received IS therapy required special attention as they became more susceptible to viral and bacterial infections. However, a higher incidence of COVID-19 had not been demonstrated in patients with RDs so far, even if they received biological Disease-Modifying Antirheumatic Drugs (DMARDs) compared with the general population ${ }^{[8-10]}$. In addition, it has been reported that patients treated with DMARDs and infected with COVID-19 do not develop lifethreatening complications due to underlying drugs ${ }^{[11]}$. Data of 600 patients in the COVID-19 Global Rheumatology Alliance registry showed similar results. In addition, most conventional synthetic DMARDs (csDMARDs) have not been associated with worse outcomes ${ }^{[12]}$. Methotrexate and LEF as DMARDs in the treatment of RDs may also exert a protective effect against COVID-19 ${ }^{[13]}$. Patients with SLE and vasculitis showed a higher tendency to be hospitalized than other patients; however, the main factor was the prednisolone dose at $10 \mathrm{mg} /$ day. It was not associated with DMARD treatment ${ }^{[13,14]}$. In our study, no effects were observed in severity and the poor prognostic factors in COVID-19 according to the type of rheumatologic disease.
It is thought that some antirheumatic drugs could be used for prevention and treatment in COVID-19 patients ${ }^{[15]}$. These include antimalarials, colchicine, GCs, JAK inhibitors, IL-6 or IL-1 antagonists, and IVIG; however, they are used to treat COVID-19 in clinical studies on weak evidence ${ }^{[16-18]}$. Furthermore, these drugs also carry a risk for viral infections. Therefore, it is still a matter of curiosity regarding whether their chronic use in RPs may change the course of COVID-19 or may be used to treat severe COVID-19 cases.

The effects of antirheumatic drugs on COVID-19 were examined in this study. Only two antirheumatic drugs affected the prognosis of the course of COVID-19. One of them was SSZ; increased ICU and mortality rates were found in patients receiving SSZ. The other antirheumatic drug was CsA, and it was observed that patients receiving CSA had less pneumonia and lower CRP. There is no study in the literature showing the effect of SSZ on the course of COVID-19. The only report on SSZ in patients with COVID-19 is that DRESS syndrome developed due to COVID-19 in a patient receiving SSZ due to ulcerative colitis $^{[19]}$. Cyclosporine can be used in the treatments of Behçet's disease, psoriatic arthritis, and lupus nephritis in rheumatology. Cyclosporine is a polypeptide immunosuppressant agent that suppresses $T$ cell responses by preventing the transcription of genes encoding IL-2. The primary molecular target of CsA is cyclophilin, a specific cytosolic-binding protein that many viruses require for replication. Therefore, it has been suggested that there may be a possible beneficial effect in patients receiving CsA during COVID-19, and many studies have supported these results ${ }^{[20-22]}$. Cyclosporine administered in addition to steroid therapy to COVID-19 patients was shown to improve the course of the disease and reduce mortality, 
especially in those with moderate to severe disease in a study by Gálvez-Romero et al. ${ }^{[23]}$. Schuurmans and Hage ${ }^{[24]}$ reported that CsA reduced mortality significantly in COVID-19 patients, resulting in an impressive survival curve significantly different compared to all other treatments. Treatment with CsA leads to a decrease in hyperinflammation and probably to a decreased viral replication ${ }^{[25]}$. Cour et al. ${ }^{[26]}$ reported that CsA could prevent uncontrolled inflammatory response, SARSCoV-2 replication, and acute lung injury. In addition, it was emphasized that CsA is a valid candidate to treat COVID-19 patients with acute respiratory failure. The Immunonephrology Working Group of the European Renal Association-European Dialysis and Transplant Association recommendations include a recent comment that $\mathrm{Cs} A$ may be the drug of choice during the COVID-19 pandemic for kidney transplant ${ }^{[27-29]}$. Our study is also important to support the positive effect of CsA on the course of COVID-19, and it suggests that it can be used in the treatment of COVID-19, similar to the other studies.

Hydroxychloroquine was presented as both a preventive and therapeutic treatment for COVID-19 at the onset of the pandemic, but it was shown to be of no benefit in later clinical studies $^{[30,31]}$. It was shown in this study that the clinical course of the patients who were receiving HCO before the COVID-19 was not better, and it had no protective effect. Moreover, CRP was higher in patients receiving HCO in our study. Other studies are investigating the clinical effects of colchicine in COVID-19 ${ }^{[32]}$. Scarsi et al. ${ }^{[33]}$ expressed that colchicine may be used in hospitalized patients with COVID-19 pneumonia and ARDS thanks to its well-known anti-inflammatory and potential antiviral properties. Patients treated with colchicine had a better survival rate in this study. A recent study demonstrated that colchicine delays the time to clinical deterioration in COVID-19 ${ }^{[34]}$. Ten patients were receiving colchicine before they were diagnosed with COVID-19 in our study. No difference was found between patients with RDs receiving or not receiving colchicine. In our study, the IL-6 inhibitor tocilizumab (TOC) was used in eight patients with a severe infection. Six patients who received TOC survived the severe infection of COVID-19, but two of them died. No patients were receiving IL-1 antagonists or JAK inhibitors for treatment since our study included patients in the early stages of the pandemic. No positive or negative effects were observed in the clinical course of patients receiving MTX, LEF, TAC, GC, and NSAIDs.

Comorbidities were significantly higher in RPs compared to the non-RPs in our study, similar to other studies ${ }^{[13]}$. In our study, more comorbid diseases were observed in patients with RDs; however, mortality rates or poor prognostic factors did not increase $^{[35]}$. It was also supported that IS drugs did not worsen the course of COVID-19 despite concomitant diseases. Therefore, it is thought that having RDs or receiving IS drugs may have a protective effect on COVID-19.

The most important limitation of our study is that it is a shortterm retrospective single-center study, and it includes patients admitted in the early period of the pandemic. However, it has been useful in determining how COVID-19 infection behaves in RPs and which risk factors are associated with a detrimental prognosis. Finally, this study may also provide some evidence on the use of antirheumatic drugs during the COVID-19 pandemic.

\section{Conclusion}

We found that RPs did not have a higher risk for infection and did not increase the severity of COVID-19 as suggested in previous studies and IS drugs except SSZ did not adversely affect the course of the disease. A significant increase in the frequency of ICU and mortality rates in patients receiving SSZ was reported. Less pneumonia and lower CRP were significantly observed in patients receiving CsA. Therefore, it is thought that $\operatorname{CsA}$ could positively affect the course of the disease and could be used to treat COVID-19 pneumonia in case of hyperinflammation.

\section{Acknowledgements}

We would like to thank Melike Yazıcı MD and Ali Erol MD for their help on the data collection of patients.

\section{Ethics}

Ethics Committee Approval: Ethics committee approval was obtained from the Bursa Yüksek İhtisas Training and Research Hospital Ethics Committee, dated 24.06.2020 and numbered 2011-KAEK-25 2020/06-10.

Informed Consent: Retrospective study.

Peer-review: Externally and internally peer-reviewed.

\section{Authorship Contributions}

Surgical and Medical Practices: K.A., Concept: S.E., Design: S.E., K.A., Data Collection or Processing: S.E., S.A., V.G., Analysis or Interpretation: S.E., K.A., Literature Search: S.E., S.A., V.G., Writing: S.E., K.A.

Conflict of Interest: No conflict of interest was declared by the authors.

Financial Disclosure: The authors declared that this study received no financial support.

\section{References}

1. Ye C, Cai S, Shen G, Guan H, Zhou L, Hu Y, Tu W, Chen Y, Yu Y, Wu X, Chen $Y$, Zhong J, Dong L. Clinical features of rheumatic patients infected with COVID-19 in Wuhan, China. Ann Rheum Dis. 2020;79:1007-13.

2. Tufan A, Avanoglu Guler A, Matucci-Cerinic M. COVID-19, immune system response, hyperinflammation and repurposing antirheumatic drugs. Turk $J$ Med Sci. 2020;50(Suppl 1):620-32. 
3. Lu C, Li S, Liu Y. Role of immunosuppressive therapy in rheumatic diseases concurrent with COVID-19. Ann Rheum Dis. 2020;79:737-9.

4. COVID-19 Rehberi. 2020. Last Accessed Date: 15.10.2021. Available from: https://covid19.saglik.gov.tr/TR-66301/covid-19-rehberi.html

5. Ochani R, Asad A, Yasmin F, Shaikh S, Khalid H, Batra S, Sohail MR, Mahmood SF, Ochani R, Arshad MH, Kumar A, Surani S. COVID-19 pandemic: from origins to outcomes. A comprehensive review of viral pathogenesis, clinical manifestations, diagnostic evaluation, and management. Infez Med. 2021;29:20-36.

6. Ye Z, Zhang $Y$, Wang $Y$, Huang Z, Song B. Chest CT manifestations of new coronavirus disease 2019 (COVID-19): a pictorial review. Eur Radiol. 2020;30:4381-9.

7. Zhou F, Yu T, Du R, Fan G, Liu Y, Liu Z, Xiang J, Wang Y, Song B, Gu X, Guan L, Wei Y, Li H, Wu X, Xu J, Tu S, Zhang Y, Chen H, Cso B. Clinical course and risk factors for mortality of adult inpatients with COVID-19 in Wuhan, China: a retrospective cohort study. Lancet. 2020;395:1054-62.

8. Michelena $X$, Borrell $H$, Lopez-Corbeto $M$, Lopez-Lasanta $M$, Moreno $E$, Pascual-Pastor M, Erra A, Serrat M, Espartal E, Anton S, Anez GA, CaparrósRuiz R, Pluma A, Trallero-Araguás E, Barceló-Bru M, Almirall M, Agustín JJD, Lladós J, Julià A, Marsal S. Incidence of COVID-19 in a cohort of adult and paediatric patients with rheumatic diseases treated with targeted biologic and synthetic disease-modifying anti-rheumatic drugs. Semin Arthritis Rheum. 2020;50:564-70.

9. Quartuccio L, Valent F, Pasut E, Tascini C, De Vita S. Prevalence of COVID-19 among patients with chronic inflammatory rheumatic diseases treated with biologic agents or small molecules: a population-based study in the first two months of COVID-19 outbreak in Italy. Joint Bone Spine. 2020;87:439-43.

10. Monti $S$, Balduzzi $S$, Delvino $P$, Bellis E, Quadrelli VS, Montecucco C. Clinical course of COVID-19 in a series of patients with chronic arthritis treated with immunosuppressive targeted therapies. Ann Rheum Dis. 2020;79:667-8.

11. Conticini E, Bargagli E, Bardelli M, Rana GD, Baldi C, Cameli P, Gentileschi S, Bennett D, Falsetti P, Lanzarone N, Bellisai F, Barreca C, D'Alessandro R, Cantarini L, Frediani B. COVID-19 pneumonia in a large cohort of patients treated with biological and targeted synthetic antirheumatic drugs. Ann Rheum Dis. 2021;80:e14.

12. Gianfrancesco M, Hyrich KL, Al-Adely $\mathrm{S}$, Carmona L, Danila MI, Gossec L, Izadi Z, Jacobsohn L, Katz P, Lawson-Tovey S, Mateus EF, Rush S, Schmajuk G, Simard J, Strangfeld A, Trupin L, Wysham KD, Bhana S, Costello W, Grainger R, Hausmann JS, Liew JW, Sirotich E, Sufka P, Wallace ZS, Yazdany J, Machado PM, Robinson PC. COVID-19 Global Rheumatology Alliance, Characteristics associated with hospitalisation for COVID-19 in people with rheumatic disease: data from the COVID-19 Global Rheumatology Alliance physician-reported registry. Ann Rheum Dis. 2020;79:859-66.

13. FAI2R/SFR/SNFMI/SOFREMIP/CRI/IMIDIATE consortium and contributors. Severity of COVID-19 and survival in patients with rheumatic and inflammatory diseases: data from the French RMD COVID-19 cohort of 694 patients. Ann Rheum Dis. 2020;80:527-38.

14. Tomelleri A, Sartorelli S, Campochiaro C, Baldissera EM, Dagna L. Impact of COVID-19 pandemic on patients with large-vessel vasculitis in Italy: a monocentric survey. Ann Rheum Dis. 2020;79:1252-3.

15. Soy M, Keser G, Atagunduz $P$, Tabak F, Atagunduz I, Kayhan S. Cytokine storm in COVID-19: pathogenesis and overview of anti-inflammatory agents used in treatment. Clin Rheumatol. 2020;39:2085-94.

16. Misra DP, Agarwal V, Gasparyan AY, Zimba O. Rheumatologists' perspective on coronavirus disease 19 (COVID-19) and potential therapeutic targets. Clin Rheumatol. 2020;39:2055-62.

17. Siemieniuk RA, Bartoszko JJ, Ge L, Zeraatkar D, Izcovich A, Kum E, PardoHernandez $H$, Qasim A, Martinez JPD, Rochwerg B, Lamontagne $F$, Han MA, Liu Q, Agarwal A, Agoritsas T, Chu DK, Couban R, Cusano E, Darzi A,
Devji T, Fang B, Fang C, Flottorp SA, Foroutan F, Ghadimi M, Heels-Ansdell D, Honarmand K, Hou L, Hou X, Ibrahim Q, Khamis A, Lam B, Loeb M, Marcucci M, McLeod SL, Motaghi S, Murthy S, Mustafa RA, Neary JD, Rada G, Riaz IB, Sadeghirad B, Sekercioglu N, Sheng L, Sreekanta A, Switzer C, Tendal B, Thabane L, Tomlinson G, Turner T, Vandvik PO, Vernooij RW, Viteri-Garcia A, Wang Y, Yao L, Ye Z, Guyatt GH, Brignardello-Petersen R. Drug treatments for covid-19: living systematic review and network metaanalysis. BMJ. 2020;370:m2980.

18. Zhang C, Wu Z, Li JW, Zhao H, Wang GO. Cytokine release syndrome in severe COVID-19: interleukin- 6 receptor antagonist tocilizumab may be the key to reduce mortality. Int J Antimicrob Agents. 2020;55:105954.

19. Balconi SN, Lopes NT, Luzzatto L, Bonamigo RR. Detection of SARS-CoV-2 in a case of DRESS by sulfasalazine: could there be a relationship with clinical importance? Int J Dermatol. 2021;60:125-6.

20. Cure $E_{1}$ Kucuk $A$, Cumhur Cure M. Cyclosporine therapy in cytokine storm due to coronavirus disease 2019 (COVID-19). Rheumatol Int 2020;40:1177-9.

21. Di Lernia V, Goldust M, Feliciani C. Covid-19 infection in psoriasis patients treated with cyclosporin. Dermatol Ther. 2020;33:e13739.

22. Molyvdas A, Matalon S. Cyclosporine: an old weapon in the fight against coronaviruses. Eur Respir J. 2020;56:2002484.

23. Gálvez-Romero JL, Palmeros-Rojas 0, Real-Ramírez FA, Sánchez-Romero $\mathrm{S}$, Tome-Maxil R, Ramírez-Sandoval MP, Olivos-Rodríguez R, FloresEncarnación SE, Cabrera-Estrada AA, Ávila-Morales J, Cortés-Sánchez V, Sarmiento-Padilla G, Tezmol-Ramírez SE, Aparicio-Hernández D, UrbinaSánchez MI, Gómez-Pluma MÁ, Cisneros-Méndez S, Rodríguez-Rivas DI, Reyes-Inurrigarro S, Cortés-Díaz G, Cruz-Delgado C, Navarro-González J, Deveaux-Homs J, Pedraza-Sánchez S. Cyclosporine A plus low-dose steroid treatment in COVID-19 improves clinical outcomes in patients with moderate to severe disease: a pilot study. J Intern Med. 2021;289:906-20.

24. Schuurmans MM, Hage R. Cyclosporine A and COVID-19 - The COQUIMA cohort. EClinicalMedicine. 2021;31:100680.

25. Sanchez-Pernaute 0, Romero-Bueno Fl, Selva-O'Callaghan A. Why choose cyclosporin a as first-line therapy in COVID-19 Pneumonia. Reumatol Clin (Engl Ed). 2020;S1699-258X(20)30044-9.

26. Cour M, Ovize $M$, Argaud L, Cyclosporine A: a valid candidate to treat COVID-19 patients with acute respiratory failure? Crit Care. 2020;24:276.

27. Anders HJ, Bruchfeld A, Fernandez Juarez GM, Floege J, Goumenos D, Turkmen K, Kooten CV, Tesar V, Segelmark M. Recommendations for the management of patients with immune-mediated kidney disease during the severe acute respiratory syndrome coronavirus 2 pandemic. Nephrol Dial Transplant. 2020;35:920-5.

28. Poulsen NN, von Brunn A, Hornum M, Blomberg Jensen M. Cyclosporine and COVID 19: Risk or favorable? Am J Transplant. 2020;20:2975-82.

29. Kemmner S, Guba MO, Schonermarck U, Stangl M, Fischereder M. Cyclosporine as a preferred calcineurin inhibitor in renal allograft recipients with COVID-19 infection. Kidney Int. 2020;98:507-8.

30. Consortium WHOST, Pan H, Peto R, Henao-Restrepo AM, Preziosi MP, Sathiyamoorthy V, Abdool Karim Q, Alejandria MM, García CH, Kieny MP, Malekzadeh R, Murthy $S$, K Srinath Reddy, Periago MR, Hanna PA, Ader F, Al-Bader AM, Alhasawi A, Allum E, Alotaibi A, Alvarez-Moreno CA, Appadoo S, Asiri A, Aukrust P, Barratt-Due A,Bellani S, Branca M, CappelPorter HBC, Cerrato N, Chow TS, Como N, Eustace J,García PJ,Godbole S, Gotuzzo E, Griskevicius L,Hamra R,Hassan M, Hassany M, Hutton D, Irmansyah I, Jancoriene L, Kirwan J, Kumar S, Lennon P, Lopardo G, Lydon P, Magrini N, Maguire T, Manevska S, Manuel O, McGinty S, Medina MT, Rubio MLM, Miranda-Montoya MC, Nel J, Nunes EP, Perola M, Portolés A, Rasmin MR, Raza A, Rees H, Reges PPS, Rogers CA, Kolawole Salami, Salvadori MI,Sinani N, Sterne JAC, Stevanovikj M, Tacconelli E, Tikkinen KAO, Trelle S, Zaid H, Røttingen JA. Soumya swaminathan repurposed 
antiviral drugs for Covid-19 - interim WHO solidarity trial results. New Eng J Med. 2021;384:497-511.

31. Mahévas M, Tran VT, Roumier M, Chabrol A, Paule R, Guillaud C, Fois E, Lepeule $R$, Szwebel TA, Lescure FX, Schlemmer F, Matignon M, Khellaf $M$, Crickx E, Terrier B, Morbieu C, Legendre P, Dang J, Schoindre Y, Pawlotsky $J M$, Michel M, Perrodeau E, Carlier N, Roche N, de Lastours V, Ourghanlian C, Kerneis $S$, Ménager $P$, Mouthon L, Audureau E, Ravaud P, Godeau B, Gallien S, Costedoat-Chalumeau N. Clinical efficacy of hydroxychloroquine in patients with covid-19 pneumonia who require oxygen: observational comparative study using routine care data. Br Med J. 2020;369:m1844.

32. Deftereos S, Giannopoulos G, Vrachatis DA, Siasos G, Giotaki SG, Cleman M, George Dangas G, Stefanadis C. Colchicine as a potent anti-inflammatory treatment in COVID-19: can we teach an old dog new tricks? Eur Heart J. 2020;6:255.

33. Scarsi $M$, Piantoni $S$, Colombo $E$, Airo $P$, Richini $D$, Miclini $M$, Bertasi $V$, Bianchi $M$, Bottone $D$, Civelli $P$, Cotelli MS, Damiolini E, Galbassini $G$, Gatta D, Ghirardelli ML, Magri R, Malamani P, Mendeni M, Molinari S, Morotti A, Salada L, Turla M, Vender A, Tincani A, Brucato A, Franceschini F, Furloni R, Andreoli L. Association between treatment with colchicine and improved survival in a single-centre cohort of adult hospitalised patients with COVID-19 pneumonia and acute respiratory distress syndrome. Ann Rheum Dis. 2020;79:1286-9.

34. Deftereos SG, Giannopoulos G, Vrachatis DA, Siasos GD, Giotaki SG, Gargalianos $P$, Metallidis $S$, Sianos G, Baltagiannis $S$, Panagopoulos $P$, Dolianitis K, Randou E, Syrigos K, Kotanidou A,Koulouris NG, Milionis $H_{1}$ Sipsas N, Gogos C, Tsoukalas G, Olympios CD, Tsagalou E, Migdalis I, Gerakari S, Angelidis C, Alexopoulos D, Davlouros P, Hahalis G, Kanonidis I, Katritsis D, Kolettis T, Manolis AS, Michalis L, Naka KK, Pyrgakis VN, Toutouzas $K P$, Triposkiadis F, Tsioufis K, Vavouranakis E, Martinèz-Dolz L, Reimers B, Stefanini GG, Cleman M, Goudevenos J, Tsiodras S, Tousoulis D, Iliodromitis E, Mehran R, Dangas G, Stefanadis C, GRECCO-19 investigators. Effect of colchicine vs standard care on cardiac and inflammatory biomarkers and clinical outcomes in patients hospitalized with coronavirus disease 2019: the GRECCO-19 randomized clinical trial. JAMA Netw Open. 2020;3:e2013136.

35. Fang $X$, Li S, Yu H, Wang P, Zhang Y, Chen Z, Li Y, Cheng L, Li W, Jia H, $\mathrm{Ma} X$. Epidemiological, comorbidity factors with severity and prognosis of COVID-19: a systematic review and meta-analysis. Aging (Albany NY). 2020;12:12493-503. 